Spring 1997

\title{
Marketing and Development in the Transition Economies of Southeast Asia: Policy Explication, Assessment, and Implications
}

Clifford J. Shultz

Loyola University Chicago, cshultz@luc.edu

Anthony Pecotich

Follow this and additional works at: https://ecommons.luc.edu/business_facpubs

Part of the Business Commons

\section{Recommended Citation}

Shultz, CJ and Pecotich, A. "Marketing and development in the transition economies of southeast Asia: policy explication, assessment, and implications" in Journal of Public Policy \& Marketing 16(1), 1997.

This Article is brought to you for free and open access by the Faculty Publications and Other Works by Department at Loyola eCommons. It has been accepted for inclusion in School of Business: Faculty Publications and Other Works by an authorized administrator of Loyola eCommons. For more information, please contact ecommons@luc.edu.

\section{(c) $($ () $\ominus$}

This work is licensed under a Creative Commons Attribution-Noncommercial-No Derivative Works 3.0 License. (c) American Marketing Association, 1997. 


\title{
Marketing and Development in the Transition Economies of Southeast Asia: Policy Explication, Assessment, and Implications
}

\author{
Clifford J. Shultz, II and Anthony Pecotich
}

\begin{abstract}
Geopolitical events have forced many countries in Southeast Asia to transform from centrally planned to market-oriented economies. The authors review the literature and introduce a model to help explain the forces and factors that seem to affect the success of Southeast Asian transition policies. The authors submit that though Southeast Asian gradualism or constrained capitalism continues to produce positive macroeconomic results and consumption opportunities, more expansive reform policies eventually could be required if these transition economies are to continue to prosper and enhance the welfare of their people. They conclude by discussing marketing implications and directions for further research.
\end{abstract}

I mpressive growth rates among the countries undergoing economic transformation in Southeast Asia have led many policy analysts, investors, and marketing planners to conclude that a Southeast Asian model of gradual transition-controlled economies guided toward the market by authoritarian governments-might be optimal for economic development. These countries - Cambodia, China, ${ }^{1}$ Laos, Myanmar, ${ }^{2}$ and Vietnam-have strengthened their economies and on balance have enhanced living conditions for their people. Indeed, the "radical" policy decisions to make economies market oriented and in turn initiate farreaching systemic changes have affected many consumers, marketing institutions, and entire societies profoundly (e.g., see Shultz, Belk, and Ger 1994). These policy changes in a Southeast Asian context, and the pace and scope of their outcomes, are sources of keen interest and debate (cf. Asian

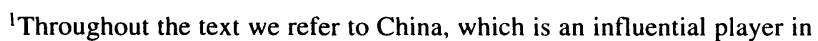
regional policymaking. The categorization of China as part of Southeast Asia can be problematic because its boundaries extend to Northeast Asia. However, labels such as Southeast Asia, East Asia, Pacific Rim, and Pacific Basin frequently are used without clear, definitive, enumerated distinction, and unique distinctions occur or have occurred only in the cases of formal alliances or associations such as the Association of Southeast Asian Nations (ASEAN), Asia-Pacific Economic Cooperation (APEC), or Asian Free Trade Association (AFTA). Our decision, therefore, is based on the desire to avoid the more cumbersome "East and Southeast Asia" description and to recognize China for its contributions to and evolving role in Southeast Asian policy and marketing development.

${ }^{2}$ Formerly Burma.
}

Clifford J. Shultz, II is an associate professor, School of Management, Arizona State University West. ANTHONY PECOTICH is an associate professor, Department of Information Management and Marketing, University of Western Australia. The authors thank the ASU FGIA and SRCA programs, the United Nations for their support of this project, Wuu-Long Lin and William Ardrey for their contributions to the formative stages of the manuscript, and the many helpful comments of the anonymous reviewers.
Survey 1996; Belk and Zhou 1986, 1987; Doner 1991; Hewison, Robison, and Rodan 1993; Kapstein 1996; Kopits and Offerdal 1994; Ljunggren 1993; Naya and Tan 1995; Robison and Goodman 1996).

We believe they also warrant further examination vis-àvis marketing and public policy. Therefore, our purpose is to synthesize the research findings and much of the academic, popular business, and institutional literature on economies in transition with the intent to (1) frame the zeitgeist on reform policies and marketing in transition economies, particularly in those countries that adhere to the Southeast Asian model; (2) illuminate what we believe are some compelling issues during economic and social transformation; and (3) provide a rudimentary model that should generate further discussion and research efforts on marketing and public policy.

\section{Policy Reform and Economic Transition}

The end of the Cold War signaled the end of "conflict between extreme forms of progressivism-socialism and neo-classical capitalism" (Sakakibara 1995, p. 8). Both of these ideologies, which emerged from the traditional feudal systems, emphasized the increase and fair distribution of material wealth as major social objectives (Fukushima 1995; Sakakibara 1995). The aim, therefore, was to solve the same economic problem and the controversy emanating from the different approaches to its resolution: The socialists emphasized state planning; the neo-classicists, the market. The collapse of the Eastern bloc not only indicated the failure to deliver an acceptable standard of living to consumers, but also suggested that the world was entering a new era of economic competition and cooperation (Weidenbaum 1995). To survive in this new age, nations will have to find structures for social and economic interaction that will allow for compromise and accommodate the needs of multiple interests. The political orientation and ensuing economic policies, as the world shifts from military to eco- 
nomic competition, must be moderated by mature pragmatism, in which "tolerance rather than impetuous belief, balance rather than progress, are respected" (Sakakibara 1995, p. 8).

This pragmatism and a desire for accommodation are perhaps most clearly visible in the transition economies of Southeast Asia, as the leaders of these states struggle to bring prosperity to their people and to maintain power. The shift away from orthodox Marxist-Leninism, however, was not the result of a grand and altogether willful conversion to capitalism; more accurately, the decision was thrust on them by a combination of economic and sociopolitical forces and policies that rendered Southeast Asia a region of disparate economic winners and losers. The obvious losers were Myanmar and the Indochinese countries of Cambodia, Laos, and Vietnam; all cases in which the ruling authorities were committed to economic management by central planning. By the mid-1980s, war devastation and/or economic mismanagement had rendered these countries among the poorest in the world, or to paraphrase Lee Kuan Yew, the world simply left them behind (Zakaria 1994). The conditions were so severe that the World Bank and other international agencies became unable to make reliable estimates, even of how poor they had become. The command economies unquestionably contributed to the deplorable poverty. It was particularly galling for the traditionally proud and xenophobic Vietnamese to see countries such as Singapore, Thailand, and Malaysia catapult their economies and living conditions so far beyond Vietnam that it will take at least 30 years to catch up. ${ }^{3}$

Nevertheless, these nations have made reformist moves toward the market system with the hope of achieving a peaceful transition to affluence - typically indicated by increases in economic growth, living standards, and the emergence of a consumer society more generally-without the cataclysmic loss of control, conflict, and internecine warfare apparent in parts of Eastern Europe (Shultz, Pecotich, and Le 1994). The difficulty of the task is compounded by the need to change an established system while lowering trade barriers and encouraging foreign investment. For example, before 1979 China was closed largely to the outside world, and the "open door" policy of 1978 ushered in a new era leading to a freeing of the market (Blaho 1994; Glassman 1991). The complexities of this task have been well described by Marer and Zecchini (1991, p. 3):

The transformation of these economic systems is, by its nature and scale, a task and an effort without precedent in economic history. The conditions of economic distress that characterize these countries at the beginning of the transition make the task all the more urgent. The lack of an adequate body of knowledge from which to draw guidance adds to the complexity of their undertaking. No 'Western' economic experience can be applied directly to solve these problems since they have unique and unprecedented characteristics related to the command-type economic mechanism and the particular economic structures that have developed over several decades.

\footnotetext{
${ }^{3}$ Thirty years is the number frequently mentioned by optimistic Vietnamese policymakers (e.g., Tran Quang Nghiem 1996); it is sometimes mentioned in casual conversation as the 2025 plan-that is, to catch up to the rest of Southeast Asia by the year 2025 .
}

This lack of knowledge is not the only impediment to progress. Another major problem stems from the entrenched nature of the extant system and the social structure within which it exists. Although these governments could be honestly seeking a formula to deliver a higher standard of living to their people, the political reality makes true progress difficult. That is, a government that champions reform and transition must produce tangible results, but radical measures and the subsequent immediate austerity often lead to erosion of public support. This turn of events then can lead to newer, regressive policies that conflict with the precarious transition policies. Another scenario might include implementation of ineffectual policies specifically implemented to mollify the various political factions, usually hard-liners within Communist parties and/or established bureaucrats who disdain change, accompanying loss of status, and the reestablishment of the bourgeoisie. For example, after making steady progress Vietnam has slowed reform. Authorities there have sentenced to jail Do Trung Hieu and Hoang Minh Chinh (leading figures in the Communist Party) for demanding greater party openness and in so doing hope to send a warning to other possible reformers (Schwarz 1995). Even more recent regressive activities such as the "social evils campaign" in Vietnam (Vietnam Business Journal 1996), Cambodia's Borgia-like political in-fighting (e.g., The Economist 1995a; Lizée 1996; Ross 1994) or the ongoing surveillance/mistrust of Aung Sang Suu Kyi in Myanmar (e.g., The Economist 1995b, c) are testimony to the volatility associated with transition.

Irrespective of these and other difficulties within the region, the extraordinary economic progress of Southeast Asia as a whole has been documented well (e.g., Solomon 1994). The full magnitude of the changes has been described as the rise of the "new economic world order" (Schwab and Smadja 1994, pp. 40-41). This advancement has led many policy analysts to conclude that there indeed might exist a Southeast Asian model of development, previously introduced as a controlled economy under the aegis of authoritarian governments transforming to a more market-oriented economy; some even suggest that, given the end of progressivism, this approach could be the template for economic development in the future (cf. Berger and Hsin-Huang 1988; Goh Keng Swee 1995; MacIntyre 1994; Wade 1992; World Bank 1993).

We refer to this model as gradualism, or constrained capitalism, because of interventionist policies implemented by authoritarian governments that tend to manage the pace and scope of the market economy. Gradualism permits state corporations to reform themselves and therefore to function like private enterprises while concurrently encouraging private businesses and a consumer culture. The objective is to transform slowly and with political stability, and in time, as stated most clearly by Vietnamese Prime Minister Vo Van Kiet (1994, p. 7), "To make our people rich." Furthermore, gradualism incorporates the core values demonstrated by the other economically successful Southeast Asian nations: respect for central authority, teamwork, outward orientation and respect for market forces, macroeconomic discipline, guided interventionism, and social/political/economic harmony (e.g., Blackburn 1994; Petri 1993, 1995). And despite the fact that these countries are still poor, trends indicate they have made sufficient headway in a short period of time, 
Figure 1. Foundations for Explication of Southeast Asian Transition Economies

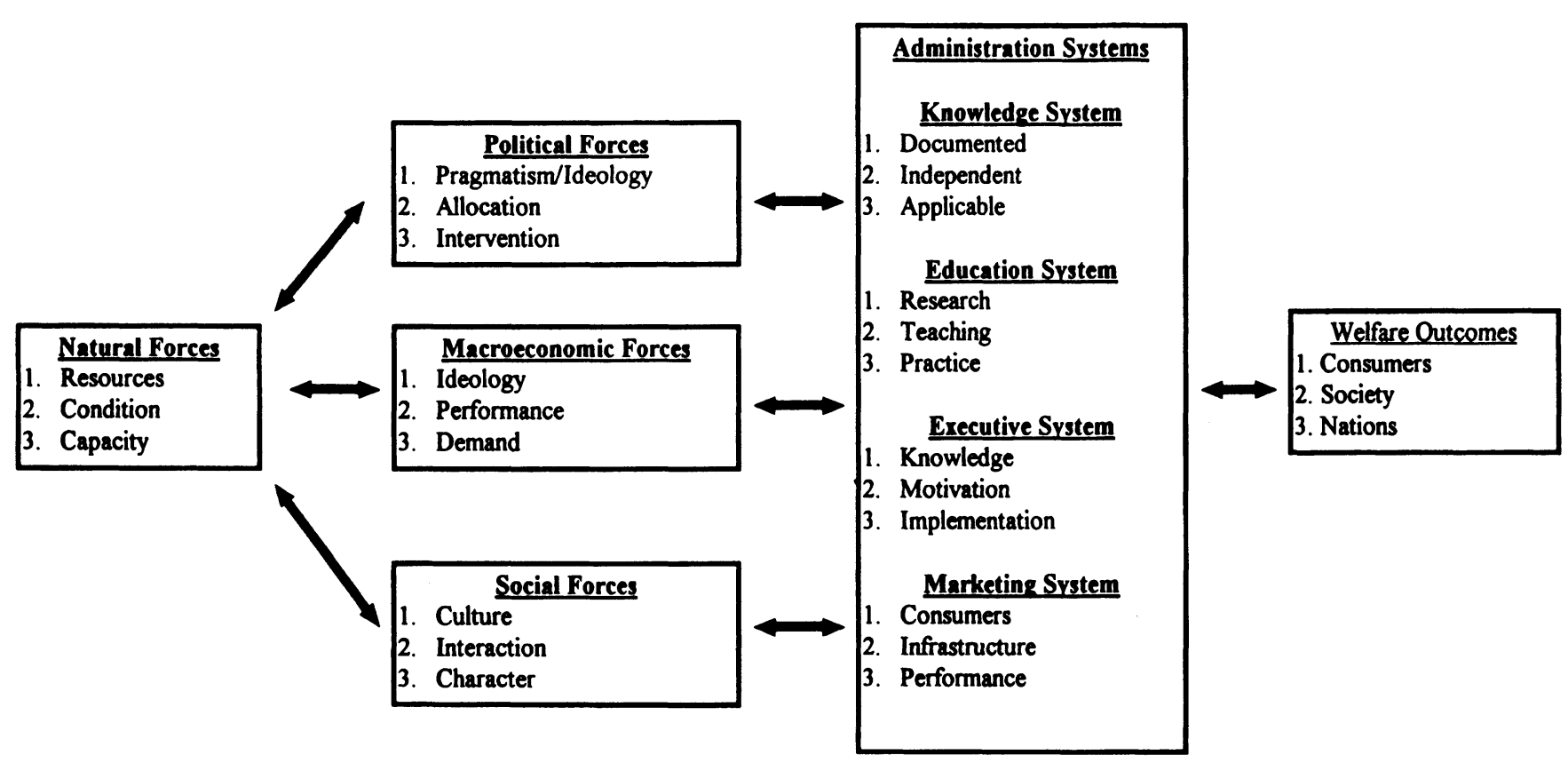

leading to the conclusion the "template" argument could have some validity.

\section{Explication of Southeast Asian Transition Economies}

To preface this section we encourage readers to note that a veracious evaluation of Southeast Asian transition economies cannot be accomplished by examining any part of any social system in isolation. To focus on any nation without a reference to the wider aspects of the environment would distort and misrepresent the events. Therefore, it is necessary to focus on the region as a whole and to extract those overarching themes that are critical to the explanation of the progress. The nations vary, for example, on the basis of culture, language, and political systems, and there are deep historical animosities among them. In some cases these animosities are so embedded in national psyches that further violent disputes are possible (Wanandi 1994), but the forces for integration and cooperation are also strong and are energized further by the pragmatic attitudes of the current leaders, many of whom share a regional vision. The trend within the region is toward international accommodation as ASEAN (Association of Southeast Asian Nations) expands and new trade blocs such as the Greater Mekong Subregion emerge (Brimble 1994), even though the conditions within many nations have not been characterized by political harmony. It remains somewhat ironic that despite greater tolerance and a movement toward regional integration, various forms of internal turmoil and repression remain problematic. (For a thoughtful discussion of authoritarianism, development, and repression in a particular Southeast Asian context, see Kyi May Kaung 1995.) Nevertheless, the movement toward regional cooperation and mutual prosperity marches forward (e.g., Chia and Pecotich 1988; Pecotich and Chia 1992).

In the following section we discuss the foundations of Southeast Asian progress that sustain the march. Figure 1 illustrates the foundations as a network of forces or systems. Each of them in turn has underlying factors that are critical to the long-term sustainable welfare of societies, nations, consumers, and regional integration. The arrows illustrate that each interacts with the others and that this interaction process is dynamic. However, though all the forces are interactive and contribute to explication, some forces are more basic than others. Consequently, they are arranged in Figure 1 from more to less rudimentary and left to right, respectively. The order of discussion is organized accordingly.

\section{Natural Forces}

Initial discussion of the model begins with natural forces because geographic attributes, natural resources, and weather patterns fundamentally determine policy and resulting market and consumer outcomes. The intrinsic habitability and natural wealth of Southeast Asia have spawned and nurtured civilizations for millennia. Indeed, its climate and resources have incited intense competition and colonial intervention to exploit the vast riches of the region and set in motion the political machinations that led to present-day transition. That is, colonialism, the struggle for control among Marxist and capitalist powers, the rise of nationalism, and the eventual administrative withdrawal of colonial and occupying powers would not have occurred unless there were extraordinary resources for which people were willing to fight and make equally extraordinary sacrifices to control. This fact might not be appreciated fully, and we address it not only because of its historical relevance, but because of its importance to current and future policy decisions. 
More specifically, each transition country varies in the condition and capacity of its natural resources, which form important geographic or natural constraints that affect the economy, markets, and consumers. Consider, for example, China's size, topography, and arable land-to-population ratio, which raise questions about this nation's ability to administer its economy and feed its people (Chang 1995; Swanson 1996). Vietnam has a coastline longer than that found between Seattle and San Diego yet is only 30 kilometers wide in some sections. Its capital, in the far North, is separated by dense rain forest from its commercial hub in the South, thus making difficult coordinated administration; its extensive coastline renders impossible the control of smuggling-which is a growing problem for the Vietnamese government (Ruderman 1996). Cambodia, the region's country with perhaps the most delicate agricultural system, is at the mercy of capricious weather patterns (Asian Development Bank 1994) and its position between the larger and more powerful Thailand and Vietnam have shaped and reshaped its borders for centuries (St. John 1995). Laos is a landlocked country with the largest land-topopulation ratio in Southeast Asia (Economist Intelligence Unit 1995). It is especially dependent on Thailand, Vietnam, and China for access to export markets and is frequently viewed by its neighbors as little more than a distribution link in the region, which in turn raises fears among Lao leaders about sustainable national sovereignty (Ardrey and Shultz 1996). Myanmar is second in land mass only to China among Southeast Asia's continental nations, and its topography and climate are almost as varied. It is wedged among India, China, Thailand, Bangladesh, and Laos, and its "crossroads" location has given it a multiethnic population with separatist inclinations (Central Intelligence Agency 1994; Economist Intelligence Unit 1994a).

Although the resources are plentiful and varied, centuries of exploitation and tremendous population pressures have led inevitably to degradation. The condition of the environment presents serious problems in most of the nations and affects their ability to enhance and sustain life quality. The conditions of some of the region's commercial hubs (e.g., Ho Chi Minh City, Phnom Penh) already have reached crisis proportions and require immense investment in urban renewal. Further economic progress will lead to greater stresses on air and water quality, traffic congestion, forest and fishery depletion, and soil erosion, thus creating a growth-preservation conundrum for these nations. Economic progress and materialism have costs, but leaders in the region, though making public statements in favor of pollution control and conservation, privately state they cannot afford comprehensive environmental protection programs. ${ }^{4}$ Political exigency demands economic growth. So, geography, natural forces, and rapidly accelerating consumption pressures increasingly will play a role in Southeast Asian policy decisions, as long as there are decisions to make.

\section{Political Forces}

The political systems in the region are now guided more by the realpolitik of pragmatism and less by ideological orien-

${ }^{4}$ Based on a series of in-country interviews by the authors with government leaders tations. Ideology, however, continues to influence the range of personal liberties, macroeconomic policies, financial allocations, social change, and the extent of intervention in other systems. Therefore, we have placed political, macroeconomic, and social forces in close proximity to one another in Figure 1 and between natural forces and systems of administration. We discuss political forces here first because the most significant impediment to even greater reform still emanates from ideological constraints.

Hesitancy and uncertainty on the part of government leaders are often due to the necessity to justify the reforms within the constraints of Marxist orthodoxy. It is perhaps inevitable that party ideologues will struggle to maintain the status quo. In some cases the struggle can take the form of archival "discoveries," which reveal that nationalist/Marxist leaders such as Ho Chi Minh might have advocated capitalist principles all along (Karnow 1996, p. 34). However, the desire to retain control, nationalism, and genuine concern for the citizenry are driving forces behind reform. These contingencies can lead to further weakening and perhaps even abandonment of the orthodoxy, especially among the younger members of the various ruling governments in the region. We have conducted numerous field interviews with Communist party members from Vietnam, Laos, and the coalition government of Cambodia and Myanmar's State Law Order and Restoration Council (SLORC). Some form of abandonment is a common theme, but many of the most talented mid-level party members committed to reform understand that to press too far would not be in the best interests of either the process or personal career management. So, the trend has been for governments to invoke a systemic market socialism-in other words, to reform from within, which entails accepting market forces and consumer culture, but maintaining control and rejecting political pluralism.

Implicit in reform policies is the understanding that party labels, icons, and symbols are becoming irrelevant. The Communist parties of Vietnam, China, Laos, Cambodia, and the SLORC of Myanmar all have accepted the importance of market economics to the success of their countries' economies and citizens' welfare. More cynically, the desire to maintain the stranglehold on power is likely to lead to further reforms. Consequently, the Communist parties and SLORC increasingly mirror the more capitalist parties that dominate politics and influence economic trends in the other, more prosperous countries of Asia (cf. Gold 1986; Haggard and Cheng 1987; Johnson 1987; Robison and Goodman 1996; Shultz and Le 1993). Ultimately, their legitimacy and longevity depend on economic growth and enhancement of life quality, and because those very outcomes are becoming increasingly evident, the reform process continues.

China frequently is seen as the vanguard. It is difficult to envision other Southeast Asian nations following policy changes forged by China, their historical rivals, but economic success and increased social well-being inevitably attract the attention of leaders in countries pushed to the brink of economic disaster. Vietnam's doi moi or renovation (e.g., Dapice and Vallely 1996; Do Duc Dinh 1993; Fforde 1993; General Statistics Office 1996; Pike 1992; Shultz 1994), Laos' chitanakan mai or new economic mechanism (e.g., Bourdet 1994; Economist Intelligence Unit 1995; Lao Peoples Democratic Republic 1995; Rigg 1995), and Cam- 
bodia's post-Paris Peace Accord ${ }^{5}$ (e.g., Prasso 1994; St. John 1995) all at least have examined and in many cases attempted to follow China's lead. The ruling generals of SLORC now have recognized the utility of economic liberalization, and policy incentives currently are producing modest if not overwhelming changes and positive consumer outcomes (cf. Abel 1996; The Economist 1996; Steinberg 1993; Sundhausen 1995; Thein and Than 1995).

Another political trend in the region is democratization. The noncommunist nations such as Singapore, Thailand, Malaysia, and Indonesia have moved in the direction of greater democracy, and as institutions develop, this augurs a more prosperous and peaceful future. The transition nations, in between bouts of repression and motivated by the disintegration of Eastern Europe and the former Soviet Union (cf. Pecotich, Renko, and Shultz 1994; Shultz, Pecotich, and Le 1994), also are democratizing their institutions slowly. The pragmatic nature of the political leadership suggests that this trend toward democratization will continue. We hasten to add that the trend is not tantamount to Western conceptions of democracy. Rather the political and economic systems are more open than they were, and thus transition seems to be inching from abject repression toward a middle-ground consumer culture: Citizens likely will be able to purchase many kinds of goods and services from around the globe, congregate and travel freely, and improve their material lot, generally, so long as they do not challenge the authority of the government (cf. Williams 1992). In effect, we are increasingly seeing a "softened authoritarianism" (Ljunggren 1992). The democratization movement is measured and incremental, and though it is generally moving forward, it is analogous to a pendulum in that it occasionally swings backward.

Internal political friction continues to hinder the reform movement. Support for reform is not unanimous among leaders, whose most critical agenda is to retain their monopoly on power. Conservatives know that macroeconomic prosperity is by no means the only outcome of reform policies. These policies also have changed the face of transition societies and threaten to bring even greater social change characterized by corruption, a widening gap between rich and poor, Western ideas on individual rights, and cries for political freedom that are imported along with investment capital and technology (Shultz, Ardrey, and Pecotich 1995). In addition to cries for political reform are pressures to embrace other ideas espoused by the world community, including respect for intellectual property rights, human rights, pollution control, environment preservation, and sustainable growth. Flagrant disregard for these issues eventually could force the world community to ostracize these governments, though the current political winds do not suggest that scenario is tenable. Economic and trade sanctions, however, would retard development, thus forcing regression to purely agrarian economies. This outcome would be especially troublesome because external pressures and the afore-

${ }^{5}$ Although transforming from a centrally planned, Marxist economy, Cambodia's situation is least reminiscent of China's, as its turning poin was brokered by the United Nations and resulted in an open election and the establishment of the Royal Government in 1993. Unfortunately, Cambodia is also the least stable country in the region. mentioned environmental constraints also would cause agricultural growth to peak in the near future and would strain the production capacity of forests, soil, and fisheries.

Clearly, political decisions ultimately affect many sectors and systems. Policies emanating from the softened authoritarianism of the Southeast Asian leadership have enhanced economic development, in many instances life quality, and for some consumers even social mobility. Irrespective of whether this authoritarianism is anchored on the "right" or the "left," Thailand, Singapore, Indonesia, Malaysia, and more recently, China, Vietnam, and Cambodia all have made advances (Asia 1996 1995; Naya and Tan 1995; Robison and Goodman 1996). Now the least developed, transition nations in the region expect to sustain their gradualism policies. In addition to obvious immediate economic incentives, such strategic decision making also helps to diversify economic risks and ultimately alleviate the consumer suffering and potential social unrest that can result when central planning fails to deliver sufficient food and other subsistence-level goods, as we are now seeing in North Korea, Asia's last orthodox, centrally planned economy (Kim 1996).

\section{Macroeconomic Forces}

Macroeconomic forces in the region tend to be shaped and influenced by three factors: (1) ideology or the aforementioned political forces, which determine the nature, structure, and operation of the economic system, including for example, privatization, deregulation, trade, and investment policies; (2) the performance of the system; and (3) the consumer demand for the products and services within and enabled by the system. Privatization, a policy that encourages privatesector participation to eliminate or modify monopoly conditions and artificial preferences for public enterprises, is instrumental in solving the ownership problem (Rondinelli, Nellis, and Cheema 1983). Accompanied by deregulation, it has increased the level of internal competition and placed considerable pressure on previously protected institutions such as telecoms and energy suppliers. The welcoming attitude to foreign investment and the deregulation of trade have resulted in a high degree of interdependence among the economies of the region. Sixty percent of the trade in Southeast Asia is intraregional, and this trend is growing at a rate of $8.1 \%$ per year (Forbes 1995; Leger 1995). This interdependence is being influenced by the pragmatic search for new ventures that contribute to the prosperity and security of the region. Concern, however, has been expressed that trade barriers could be coming down much faster than is desired or expected (Asian Business 1995), and domestic political realities could curb this general trend. The advance toward free trade, therefore, could be uneven, but it seems unlikely that it will be reversed permanently.

Privatization, competition, and trade have stimulated technology diffusion. Countries that were condemned previously to low-technology, labor-intensive technologies are now able to produce sophisticated high-technology products at low cost (Schwab and Smadja 1994), thus breaking the links between high technology, high productivity, high quality, and high wages. The policy of relying on cheap labor for competitive advantage is likely to lose favor. The labor cost edge might be retained, in the short term vis-à-vis external competition from the United States and Europe, but it is not 
a viable foundation for a sound future within the region, where the flexible corporation could move from Thailand to China to Vietnam and so on. Moreover, in some of the nations (e.g., Vietnam, Cambodia), labor cost advantages seem to vanish in the realities of day-to-day business, including rent extractions, power shortages, and the like.

All the transition economies face problems creating incentives to initiate and run efficient businesses and mobilize investment. There is no easy formula to solve these problems, but gradual reform has permitted wealth to be generated and protected, thus helping to create legal and financial infrastructures to expedite the reform process. Moreover, families can "nest" capital, in essence becoming mini-banks from which contiguous families or community members can borrow. This practice of informal savings and loan arrangements among families and friends is common throughout Southeast Asia (e.g., Le Ngoc Hung and Rondinelli 1993). Venture capital then can be used for entrepreneurship that can deliver goods and services to pent-up consumer demand. Indeed, this new entrepreneur-consumer relationship seems to be a pillar of the marketization renaissance (United Nations 1993a). For example, in China, Deng Xiaoping's reform policies permitted farmers or entrepreneurs to achieve modest wealth by responding to consumer demand and thus contributing to national welfare; these same policies enabled government to establish commercial enterprises. Vietnamese leaders observed the outcomes in China and implemented similar reforms. Initial Vietnamese efforts were supported by the countless small farmers and small-scale entrepreneurs. In less than a decade SMEs (small- to medium-sized enterprises) and privatized SOEs (state-owned enterprises) have become a dynamic economic foundation for the nation (Shultz, Low, and Ardrey, in press). Laos, Cambodia, and now Myanmar subsequently have enacted many of the macroeconomic reforms implemented in China and Vietnam. Included among these are the acceptance of private sector activity, the reversal of agricultural collectivization, a shift from central planning to a market economy, and the removal of price controls and subsidies to improve the countries' dismal economic performances. The economic development policies espoused by government representatives from Laos (Alounkeo Kittikhoun 1995), Cambodia (Tan Savuth 1994), Vietnam (Le Van Bang 1995), and Myanmar (Abel 1996) stress commitment to further reforms.

Vietnam, eventually Cambodia and Laos, and now Myanmar hope to follow China to the next step of more sophisticated entrepreneurial enterprises and the advent of industries whose products will be capable of competing in the global market. Productivity and export measures indicate that each of these countries has made progress in these areas (Asia 1996 1995). However, some Western policy analysts believe this evolutionary process ultimately is destined to fail because they view "communist states" as inevitably totalitarian in nature and therefore a deterrent to entrepreneurship (e.g., Goodman 1996). More thoughtful analysis of recent trends tends to view market socialism more broadly, that is, as a consolidation of power by a single party that tries to mobilize and change society through incentive structures manipulated by revised, ideologically determined standards of behavior. Market socialism has changed the incen- tive structures to reward entrepreneurship, and entrepreneurs are now endemic to the countries in transition.

Regardless of the strength of the entrepreneurial ethos, we cannot expect a far-reaching transformation that is national in scope without political and economic linkages among the powerful and influential nations that tend to harbor large reserves of capital and expertise. Economic success stories throughout Southeast Asia support this argument. By accessing these reserves, former less-developed countries have expedited the removal of many of the disabling conditions that nationalism and bureaucracy impose on business growth and created an ideological and economic environment that facilitates agendas among the power elite. The market development that has spurred Southeast Asia's recent growth probably would not have occurred without arrangements negotiated at the highest level among entrepreneurs, bureaucratic chiefs, and foreign sources of aid, investment, and markets (McVey 1992, p. 9). This lesson has not been lost on the leaders of the region's transition economies. Market socialists in Laos, Cambodia, Vietnam, and the SLORC now accept this development requisite. They increasingly work to channel citizens' energies toward economic goals and to attract foreign investment capital, while discouraging political reform. We have not yet seen economic shock therapy as a mechanism to break down these networks. Rather, these networks are used to induce positive economic results. Not coincidentally, government officials enjoy perks, promotions, and special investment opportunities; they share in free market economic successes and become supporters of new small businesses in the areas they control. Whether such favoritism can be sustained has yet to be determined. Some have argued the region's transition economies eventually will be served better by initiating further reforms to decentralize and allow even greater numbers of entrepreneurs to flourish (cf. United Nations 1993; The Wall Street Journal 1996).

\section{Social Forces}

We temper the preceding discussion with a healthy respect for social forces, which for reasons of parsimony we loosely categorize as culture, interaction, and character. In these conceptualizations, culture determines the most general, enduring set of values within the community (cf. Goodenough 1971; Hofstede 1980). For example, the community could value commerce, altruism, material possessions, and/or formal education, or it could have shared values in apposition to all or some of these constructs. Interaction is used here as a term indicating the extent of the open or closed nature of the society, that is, freedom of interaction. Character is used to refer to the characteristics of the society-for example, the demographic structure.

The ethnocentric, uninitiated observer of the region could use false broad categorizations such as "Asian" or "Chinese" to indicate a degree of homogeneity, which simply does not exist in Southeast Asia. Cultures, similar to nations, are "imagined communities" (Anderson 1995) among which there exists a vast diversity within each of the nations even without reference to national differences across Southeast Asia. Although some countries (e.g., Cambodia) are more culturally homogenous than others (e.g., Myanmar), within all the nations there exist cultural differences (including lan- 
guage, religion, and ethnicity) that preclude a simple enumeration (cf. Parrinder 1995). These differences present a challenge to further progress for not only the region, but the nations themselves. At an extreme level, cultural differences, as much as economic disparity, have played a significant role in the region's hostilities (e.g., Khmer attacks on Vietnamese fisherman in the Tonle Sap, Vietnamese assaults on Cholon Chinese, SLORC's military engagements with Karen separatists). However, it is also true that some of the nations in the region, at least on the surface, present a visible degree of cultural harmony and coexistence (e.g., Singapore). Furthermore, the pragmatism, the positive cultural attitudes to marketing and business, and the shared educational experiences of some of the major cultural groupings suggest that a slow evolution toward cultural reconciliation is possible, especially if mutual benefits of economic cooperation are to emerge. And though the underlying authoritarian paternalism that can make this possible is sometimes repugnant to Westerners, there is an element of a cultural truth in the following statement by Lee Kuan Yew:

To this day, the majority of [Southeast Asians] do not want to be actively involved in political parties.... What they want is to have somebody governing them well and producing things that they want (Kamm 1995, p. 13).

Accordingly, the view that the economic progress of Southeast Asia is due to Confucian values of education, hard work, thrift, and social order has much currency in the East and the West (cf. Robison and Goodman 1995, p. 3).

The existence of immigrant groups (e.g., the overseas Chinese) and interaction among cultures generally can serve as a cultural bridge between nations as well as a source of investment capital (Kraar 1993). Unfortunately, ethnic and political tensions still frequently impede investment from groups most keen to invest. Viet Kieu (i.e., overseas Vietnamese with skills and capital) are often reluctant to return because they remain fearful of a policy reversal in Hanoi. A similar problem exists for overseas Cambodians, Laotians, and Burmese. Similarly, the Chinese Diaspora also has contributed greatly to the economy of Southeast Asia (Chang 1995, p. 955), though they have not always been well treated in Vietnam and other Southeast Asian countries (e.g., Taft 1994). Both the Chinese and Viet Kieu can be motivated to invest in Vietnam, for example-and some are investing despite the cool reception by the government-but policy reversals will make massive amounts of capital difficult to attract. Therefore, the reform movement would be stunted unless policies address cultural sensitivities and stimulate cross-cultural interaction and ultimately mutual gain.

With regard to the character of the region, the evidence suggests that, demographically, despite the need for caution that prudent pragmatism dictates, the sheer weight of numbers will continue to propel further growth. The size, density, and growth rates of Southeast Asia make it integral to the global economic community. The region, depending on which nations are included, contains as much as $50 \%$ of the world's population while occupying only about $20 \%$ of the total land mass. This statistic includes China, the world's most populous nation, and five other nations with populations of more than 40 million (Indonesia, 199.7 million;
Myanmar, 45.4 million; Philippines, 68.7 million; Thailand, 59.4 million; and Vietnam, 74 million). Some of the fastestgrowing populations are also found in Southeast Asia: Cambodia (9.9 million) and Laos (4.7 million) are both growing at annual rates of $2.9 \%$ (Central Intelligence Agency 1994). Moreover, the populace tends to be dispersed in rural areas, but an emerging rural-urban drift is presenting major problems. In many instances the movement from the country to the city has occurred too fast and has strained the socioeconomic infrastructure, leading to increased unemployment and the development of slums and a disenfranchised segment of society. Furthermore, Williams (1995, p. 5) in a discussion of regional demographic trends has stated that:

Sex, together with age, is one of the two most important controls of future growth, and also, incidentally, of social ranking. In countries that are aiming towards development, the position and proportion of women and youth in society are important because of their influence on the composition of the workforce, their ability to contribute to national prosperity, and their ability to reproduce and so contribute to future population growth.

This observation suggests that the burden of dependence might be high, but because Southeast Asia's population overall is younger than other parts of the world (more than half of the people are under 25 years of age, compared with the United States, in which the proportion is about a third, and Europe about a quarter) the demographic base for further economic growth also exists. This is not to discount that the dynamics of the population changes are many-including migration patterns, fertility rates, and mortality and life expectancies-all of which are changing and will have an impact on the development of the region. Other demographic problems include population shifts resulting from the movement across borders by "guest workers," such as prostitutes and child laborers, and the tragic plight of refugees. Rising, balanced, long-term prosperity of the region could provide the solution to many of these problems.

\section{Administration Systems}

A modern state whose leaders hope to be competitive in a global economy cannot progress without the existence of a well-established and protected knowledge base, institutions to create and disseminate knowledge, and an apparatus to manage knowledge and other resources. A review of Figure 1 indicates we have subsumed these entities in "administration" because, though each is administered interactively, their mutual outcomes tend to be co-dependent, and the content and process of each tend to be a function of the preceding forces.

\section{Knowledge System}

The knowledge system is the source of collective wisdom that ensures the transfer of experience and provides the foundation for innovation and change. The three components of this system are (1) the extent to which knowledge is well documented - that is, the degree to which knowledge is stored and diffusion technology facilities are readily available; (2) the degree to which it is independent-that is, can be relied on to be objective and free of ideological influence; and (3) the degree to which it is applicable to market development and transition contexts. 
All the transition nations have undergone a revolutionary phase, during which deliberate and often uncontrolled destruction of the historical knowledge base took place. Some nations such as Cambodia are emerging from what can only be described as one of the most horrific sociopolitical experiments in the history of humanity, during which almost a third of the population and the entire intelligentsia were lost (Chandler 1992). Losses of this kind followed by periods of strict censorship can cause irreparable damage not only in economic terms but more importantly to the collective psyche (Mydans 1996; Shenon 1995; Tith and Shultz 1996). Fortunately, the leadership of even the most disadvantaged of these nations seems to be recognizing that a nation cannot advance without a documented basis for expertise (cf. Schultz 1960; Simon 1988) and that concentrated experience (e.g., USAID and non-governmental projects in the forms of university and library development and visiting scholar programs), which facilitate the (re)establishment of recorded knowledge, is critical for the progress of the region. Knowledge advancement and dissemination, however, is another agenda hotly contested between reformers and conservatives. A problem facing the reformers is the capacity of the ideologically conservative group to block reform by appealing to nationalism and the need to preserve cultural purity (e.g., Nguyen Duy Khien 1996). Nevertheless, and regardless of "need," it will be increasingly difficult to restrict access to databases and the flow of information through international networks. Moreover, it is evident that all but the most dogged conservatives understand that competitive economies - and implicitly national strength and independence-increasingly are linked to information technologies. Consequently, major public policy initiatives continue to be concerned with the management of the information technology boom.

\section{Education System}

The institutional conduit of knowledge will be an effective education apparatus, and for economic transformation and development to be successful, governments must place a great emphasis on the production of a trained and educated workforce (cf. Goh Keng Swee 1995, pp. 237-42). A macro assessment would suggest that, essentially, this apparatus consists of teaching, research, and practice. The practice component is emphasized because commerce and marketing are applied disciplines, and the test of the relevance of the knowledge development and teaching and research efficiency is in the effectiveness of application. Governments are facing some critical policy decisions that not only will affect the education system, but will have long-term "ripple effects" for the other administration systems. For example, should provision of education be public or private? Who should have access? Should the mastery of technical skills be emphasized? Which if any national models are most appropriate? There are many innovative possibilities in this area, including distance education, hybrid models combining the best attributes of various national systems, as well as a revolutionary option of unified regional action; but fundamentally, an education system that enables a comprehensive and competitive knowledge system is critical.

\section{Marketing and Executive Systems}

Knowledge and its advancement and dissemination will have to be leveraged and managed in an effective administrative apparatus; therefore the final components are the executive and marketing systems. Although we list these systems separately in Figure 1, we discuss them under one subheading because of the inherent role of executive and management decision making to effective marketing practice. Fundamentally, we refer to the professional practice of government and business marketing management. The quality of it depends on the knowledge level of the executive/ management population, its motivation, and the extent to which it actually implements modern marketing practices. In many respects the rapid growth among the transition economies is evidence of a rudimentary understanding of marketing practice.

The basic problem involves training a critical mass of managers and executives capable of administering organizations that can compete in a global economy. Frequently, even the most ambitious apparatchiks and budding executives have little knowledge of the philosophy and tools that are conducive to successful marketing management. An entire generation (or more) exists that has no knowledge of anything but the communist system. Human resources, therefore, are critical to transition. Returning nationals educated in the West are an important resource of marketing skills. Furthermore, some reformers have the good fortune to administer nations whose citizens have firm recollections of capitalist traditions (e.g., southern Vietnamese) and therefore have been able to make more rapid transitions. Another important factor has been a dedicated and trained professional bureaucracy committed to economic reform and armed with the knowledge required to work in or to manage a marketing system effectively. Again, to use China's transition as an illustration, the reform movement cultivated bureaucratic and even military allies to sustain reform policies. Accumulating wealth became not only permissible, but possible, as relevant stakeholders within the public sector recognized politically correct opportunities to prosper and maintain power (Overholt 1993).

Transition has demonstrated that, from a marco perspective, marketing involves the orchestration of natural, political, social, and macroeconomic forces to assist in the reconciliation of supply and demand through exchange process(es). The exchange or transaction is central to the process (cf. Bagozzi 1975), and at the micro level it is critical that systems exist to facilitate exchanges that are expected to be voluntary and beneficial to all participants (e.g., Meade and Nason 1991). A role of government is to assist the unencumbered exchange process and to balance its efficient and equitable functioning. Essentially, governments of Southeast Asia's transition economies seem to have recognized grudgingly that the way forward could be less intervention, which will enable marketing systems to evolve and result in consumer and societal benefits.

Marketing also involves managerial processes, however, and it is at the micro level where the strongest reforms still are needed, for whatever the ideological shift, further progress cannot be made without changes to the corporate structure. A cornerstone of the Western marketing paradigm is the so-called marketing concept (e.g., Kotler 1994), 
essentially, a normative philosophical imperative on which modern marketing practice is based. Paraphrased, the dictum is that marketing managers should pursue profit through a consumer orientation and an integrated strategy. The driving force behind the marketing system is consumer needs, the satisfaction of which leads to profit. In this can be seen the critical error of controlled economies, whose raison d'être to increase the material welfare of their people was exemplary, but who failed because of their disregard for marketing management principles. In addition, the failure to emphasize profit as a fundamental driving force of business doomed many of these nations to poverty because of the inevitable lack of capital for reinvestment. Moreover, though market advocates tended to emphasize price, in practice many problems arose not so much from prices and price setting but rather from profit and its distribution. Profit, which is too often viewed as "exploitative," could be viewed more accurately as a performance indicator; but in these nations profit generally was regarded as a capitalist evil and therefore as having no function in a socialist economy. Even when a corporation enjoyed a surplus, its disposition was controlled by the government (the party), whose investment decisions were dominated by political power and ideological considerations rather than by national economic concerns and individual corporate or consumer welfare.

Policies in relation to other marketing functions were based on a poor understanding of marketing theory and were too often openly hostile to marketing practice. Marketing communications provides a good example. In China, advertising was under tight state control until reformers suggested that advertising could be instrumental to the reciprocal relationship between consumption and production and might prove to be an important catalyst to economic development, and therefore was not as subversive as was thought previously (Swanson 1990). Since the reforms, the growth of advertising expenditure has been exponential, culminating with US $\$ 860$ million in the first half of 1994-a $73 \%$ increase from the previous year (Simons 1994) - and has sparked keen interest among academics (cf. Pollay, Tse, and Wang 1990; Semenik, Zhou, and Moore 1986; Swanson 1990; Tse, Belk, and Zhou 1989; Zhou and Belk 1993). Indeed, promotion is a well-developed marketing mix element in many of the transition economies and has been instrumental to successful market penetration and consumer decision making in Cambodia, Laos, Myanmar, and Vietnam, as well as in China. It has become so effective that it has been regarded as a contributing factor to Vietnam's social evils campaign (Vietnam Business Journal 1996, p. 16) and SLORC's decision to regulate tightly-through the Ministry of Information-all advertising content, media, and timing.

Product policy, as with other elements, also was controlled centrally. It was the responsibility of technical production cadres guided by party ideologues. Industrialization schemes funded by a strong agricultural sector forced a focus on commodity and heavy-industry production. An implication is the utter disregard for marketing research. This important function was virtually nonexistent in most of the controlled-cum-transition economies, and marketing research agencies are only just beginning to appear in, for example, Laos and Myanmar. The general ignorance of marketing and in particular consumer behavior as well as the lack of infrastructure development had some disastrous consequences such as famine (e.g., Karnow 1991, p. 43).

Poor development of distribution and transportation infrastructure contributed-and continues to contribute-to these problems. Further economic progress cannot be achieved without a rapid development of distribution channels. For example, Myanmar, which is approximately $25 \%$ larger than Thailand, has approximately $40 \%$ fewer kilometers of highway (Central Intelligence Agency 1994). Seaports in Vietnam are in disrepair or incapable of unloading large container ships (General Statistics Office 1995); Cambodia's countryside is pocked with explosive ordnance, and Laos has underdeveloped rail and highway conduits (Asian Development Bank 1993; Economist Intelligence Unit 1994b; International Monetary Fund 1994).

These are but a few examples of the importance of marketing mix variables to the economic and social success of transition economies. In short, strategically managing the marketing mix is paramount to the long-term success of government run firms and organizations and to the newly privatized or emerging private-sector firms, sustainable growth, and consumer welfare. And though this thought might be painfully obvious to marketing practitioners, policy analysts, and scholars in established market economies, it is still frequently lost on many of the policymakers in transition economies.

\section{Discussion}

\section{Policy and Welfare Outcomes}

We suggest that the Southeast Asian model of transition demonstrates an effective sensitivity to the complex interactions of many forces and systems. In so doing, it enables the change process to build the necessary institutions, while avoiding fatal damage to price stability, social harmony, or political support for future reform. The model certainly is not flawless, but the Chinese experience and more recently the experiences in Vietnam, Cambodia, Laos, and Myanmar have shown that a centrally planned economic system can adopt rudiments of a market system without an intervening social catastrophe-a conclusion that would be much in doubt if these countries had pursued the shock therapy strategies favored in Eastern Europe, which antagonized too many groups simultaneously, incited opposition, and ultimately stymied transition (cf. Goldman 1991; Overholt 1993, p. 46). The essence of successful reform policies is usually a willingness or ability to divide the process into manageable phases and build a political constituency of supporters who see reform as serving their interests. Therefore, shock therapy, in which political reform outpaces economic reform, has led many observers to conclude "an effective transition to the market system can be possible only in the context of economic development ... [and] on the creation of new capacities and not only-or primarily - on the dismantling of the old capacities" (United Nations 1992, p. 3).

Throughout the process political pluralism has been rejected by the Southeast Asians, or at least Southeast Asian governments. SLORC and the "Communist" parties, promoting their softened authoritarianism rather than draconian political repression, remain in control. Moreover, their governments have been able to reduce inflation to tolerable lev- 
els, while improving life quality for many of their citizens. In countries where gross domestic product per capita hovers around $\$ 200$ to $\$ 600$, and the slightest improvements become apparent, it would seem that the majority of citizens believe political pluralism can wait as long as the transition process produces improvements in living standards across a broad social spectrum of consumers. By delivering the goods, literally and figuratively, the leaders of Southeast Asia's transition economies are hopeful that they can avoid social and economic disintegration. At this juncture-and certainly relative to conditions a decade ago-it would not be unreasonable to conclude that gradualism in the form of market socialism has been "successful" because it has helped to balance macroeconomic forces, political control, and societal welfare.

Having rejected rapid reforms and Western political values, the leaders of Southeast Asia's transition economies look to China and, increasingly, Singapore as models to sustain their transformations. Given extant resources and by orchestrating political, marcoeconomic, and social forces the countries are designing administration systems that interact with marketing systems to produce impressive growth figures and some positive consumer outcomes. Yet, we contend these countries eventually will hit what we call the "transition wall"-flattening growth curves, competition for investment capital, and a more informed consumer society that will become impatient with gradualism. Hence, more expansive policies to introduce new technologies, access to information, and greater private sector control will be required if leaders hope to enable further growth, global competitiveness, and the most optimal outcomes for consumers. These more expansive policies also will stimulate information dissemination and greater pressures for political reform, or, depending on a country's orientation, "corrupting influences" such as Western ideas encouraging iconoclasm, nonconformity, and dissent.

\section{Marketing Implications}

Leaders of the transition economies will try to administer the forces and systems presented in Figure 1 by replicating many of the policy formulas that spurred growth in other parts of Southeast Asia: relatively stable political environments, guided market economies, foreign investment, cheap labor, and export development. They also will try to access expertise and management practices, not only from their more wealthy regional neighbors, but from other nations and sources as well. These contingencies create promising opportunities for marketers in the areas of education, energy, transportation, construction, consumer and industrial products, and communication. The consumer base already exists and is awesome, and though the consumers in the transition economies are generally poor and "unsophisticated," this too is changing. An increase already has occurred in domestic consumption due to the emergence of a middle class with activated needs, rising expectations, and the disposable income to spend for their satisfaction. The marketing and consumption conditions exploding in $\mathrm{Ho} \mathrm{Chi}$ Minh City, Yangon, Mandalay, Hanoi, Phnom Penh, Vientiane, and the cities of southern and coastal China are precursors of events to come and indicators of the possibilities. The sheer potential of these countries has inspired massive foreign investment and multilateral aid. These trends now force marketers to consider whether they can afford not to be in these markets.

The benefits of participation could augment a regional strategy. Firms can protect international market share and capitalize on the strength of regional movements, such as ASEAN, the Greater Mekong Subregion, and the pandemic emergence of consumer culture. These movements will inspire further cooperation and some standardization. Ultimately, strategic participation must consider corporate ambitions, position, resources, and organization, while focusing on specific transition economies and also diverse, arcane conditions within these countries (cf. Lasserre and Schütte 1995, p. 24).

It is important to strive for multi-stakeholder benefits from investment. Interviews with government authorities and investors in Cambodia, Laos, Myanmar, and Vietnam indicate none of the governments want transition to culminate in their countries becoming little more than export markets for other countries' consumer and industrial products. Instead they seek mutually beneficial projects. This objective affects marketing practices, which are encouraged to ensure successful transition and profitable ventures. More specifically, marketers are encouraged to stimulate economic growth and, ideally, to improve living standards for the largest number of people. Governments provide tax incentives, favorable locations, and other incentives for firms that initiate projects with mutually beneficial outcomes. Types of projects most frequently mentioned include all facets of infrastructure development, particularly transportation, sanitation, and telecommunications; agricultural marketing; manufacturing facilities; and value-added industries. In short, projects that build or restore infrastructure, develop natural and human resources, share technology, and develop export marketing receive considerable support from multilateral aid sources and local authorities. More recently, projects that facilitate sustainable growth and development have been favored.

The opportunities in transitional Southeast Asia are not without risks. The administrative and organizational problems are immense and, without resolution, could destroy the potential. Balancing marketer interests with ongoing legal and political constraints, environment and culture preservation, and the growing demands of a voracious consumer culture will be extraordinarily difficult. These nations need not only capital, goods, and services but assistance in developing a new form of marketing system. Legal and financial institutions are inadequate; human resources typically are ill-equipped to prosper in a complex marketing system. Investors therefore might need to provide assistance in developing all elements of the model illustrated in Figure 1. Indeed, administering a comprehensive strategy is the greatest challenge confronting marketers. The labor force, including managers, has little knowledge about or experience with the marketing practices of the West or Asia's developed economies. This is particularly true in newly privatized firms in which the personnel were, in effect, political appointments. So, a marketing executive could have several roles to play. He or she might be required to develop specific strategies for successful market entry, assist in the creation of an enabling environment in which business can 
flourish, restructure the organization, train employees, and/or establish a marketing ethos within the organization.

Political and social institutions throughout Southeast Asia's transition economies are becoming more marketing friendly, thus enabling marketing and executive systems to be more efficient and effective. Local workforces ordinarily are very keen to work for international firms and master the skills required to succeed in marketing organizations. And governments do want investors to succeed, within the context of win-win outcomes. "More marketing friendly," however, is a relative description. Corruption and rent extractions are still common, employees must be trained to perform the most basic business tasks, and marketers generally are asked to succeed in a marketing environment in which the rules are changing as the game is being played. These pitfalls are the very nature of transition. In summary, marketing in these countries has been likened to playing football with moving goal posts: Just when it seems one is about to score, a new law is passed, policy shifts, bureaucrats interfere, electricity fails, orders are delayed, the distribution network collapses, and so on-that is, the goal posts move. Because of this unpredictability and uncertainty, successful marketers have added prudence, patience, and perseverance to the marketing mix (Shultz and Ardrey 1997).

\section{Future Research Directions}

Southeast Asia's transition economies are unique living laboratories in which to study the dynamic interaction of socioeconomic policy change, marketing, and consumption. We propose a model to explain the foundations of transition. In light of the analysis and discussion presented here, we believe the following suggestions are the most compelling research opportunities.

The model is not exhaustive, and further development is appropriate. This could include, first, discussion and expansion of the foundations. Second, empirical tests of the relationships among the various forces, factors, and systems are needed. Empirical testing could include within-country analyses, but cross-cultural and international comparisons would be especially fruitful. These efforts would enable us to determine which variables and combinations of variables are most likely to contribute to individual and societal prosperity. To that end, perhaps the single most compelling direction for further research would include more expansive conceptualizations and operationalizations of the construct-welfare outcomes. We have selected this descriptor purposely to stimulate thinking beyond the more normative and restrictive terms-development and progress-which connote economic gains and typically are measured by economic growth, inflation rates, per capita income, and purchasing power parity. Material possessions, as measured by some sort of standard package (cf. Keyfitz 1982), are also fairly typical. We encourage marketing scholars and policy analysts to consider broader life quality measures, including, for example, health and wellness indicators, literacy, anomie, angst, social mobility, and perhaps social harmony and cultural (dis)integration (cf. Belk 1988, pp. 118-22; Dholakia and Firat 1988). We submit that if governments, societies, consumers, and marketers accept that Southeast Asian transition is both inevitable and desirable, it behooves all of us to determine what will be its long-term and far-reaching effects.

\section{References}

Abel, David (1996), [Brigadier-General and Minister, Ministry of National Planning and Economic Development] "Keynote Address: An Overview of Myanmar's Economy," Myanmar Business Roundtable, March 14, Yangon.

Alounkeo Kittikhoun (1995), [Ambassador to the Permanent Mission of the Lao Peoples Democratic Republic] interview with author, December 3, New York.

Anderson, Benedict (1995), Imagined Communities. London: Verso.

Ardrey, William J. and Clifford J. Shultz II (1996), "Laos: Marketing and Consumer Behavior in the Heart of the Golden Quadrangle," working paper, Arizona State University West.

Asia 1996 (1995), Hong Kong: Far Eastern Economic Review Publishing Company.

Asian Business (1995), "The Challenge of Change," January, 20-24.

Asian Development Bank (1993), Lao People's Democratic Republic: Economic Update. Manila: ADB Press.

(1994), Cambodia Economic Update. Manila: ADB Press.

Asian Survey (1996), “A Survey of Asia in 1995: Part I," Vol. 36. Berkeley: University of California Press.

$\rightarrow$ Bagozzi, Richard (1975), "Marketing as Exchange," Journal of Marketing, 39 (4), 32-39.

Belk, Russell W. (1988), "Third World Consumer Culture," in Marketing and Development: Toward Broader Dimensions, E. Kumcu and A.F. Firat, eds. Greenwich, CT: JAI Press, 103-27.

- and Nan Zhou (1986), "Emerging Consumer Culture in the People's Republic of China," in The Role of Marketing in Development: Global Consumer and Managerial Issues, Erdogan Kumcu, A. F. Firat, Mehmet Karafakioglu, Muhittin Karabulut, and Mehment Oluc, eds. Muncie, IN: Ball State University Press, 137-45.

- and (1987), "Learning to Want Things," in Advances in Consumer Research, Vol. 14, Melanie Wallendorf and Paul Anderson, eds. Provo, UT: Association for Consumer Research, 478-81.

Berger, Peter and Michael Hsiao Hsin-Huang (1988), In Search of an East Asian Developmental Model. New Brunswick, NJ: Transaction Books.

Blackburn, Kevin (1994), "Does the West Need to Learn 'Asian Values'?" IPA Review, 47 (2), 35-36.

Blaho, Andras (1994), Russian Transition-Chinese Reforms: A Comparative View, United Nations University. New York: Wider.

Bourdet, Yves (1994), "Laos: The Economic Mechanisms and After?" Mimeograph 52/94, Department of Economics, University of Lund.

Brimble, Peter (1994), "From Thailand to the Greater Mekong Subregion: The Challenges for Private Business," Brooker Group Limited paper presented May 1, Bangkok.

Central Intelligence Agency (1994), The World Fact Book. Washington, DC: U.S. Government Printing Office.

Chandler, David P. (1992), A History of Cambodia. Boulder, CO: Westview Press. 
Chang, Maria Hsia (1995), "Greater China and the Chinese 'Global Tribe,"' Asian Survey, 35 (October), 955-67.

Chia, Hock Hwa and A. Pecotich (1988), "Multinational Management and ASEAN Regional Development," Asia Pacific Journal of Management, 6 (1), 161-74.

Dapice, David and Thomas Vallely (1996), "Vietnam's Economy: Will It Get and Stay on the Dragon's Trail?" unpublished research report. Cambridge, MA: Harvard Institute for International Development.

Dholakia, Nikhilesh and A. Fuat Firat (1988), "Development in an Era of Globalizing Markets and Cosnsumption Patterns," in Marketing and Development: Toward Broader Dimensions, E. Kumcu and A.F. Firat, eds. Greenwich, CT: JAI Press, 79-101.

Do Duc Dinh (1993), "Vietnam's Economic Renovation to the Market Mechanism," Journal of Asian Business, 9 (Summer), 17-33.

Doner, Richard F. (1991), "Approaches to the Politics of Economic Growth in Southeast Asia," The Journal of Asian Studies, 50 (November), 818-49.

The Economist (1995a), "Cambodia on the Slide," (December 16), 32.

_ (1995b), "The New Light of Myanmar," (July 15), 23.

- (1995c), "Myanmar's Perilous Future," (July 22), 33-34.

(1996), "Myanmar's Mysterious Boom," (April 6), 35-36.

Economist Intelligence Unit (1994a), Country Profiles: Thailand and Myanmar. London: EIU Ltd.

(1994b), Indochina Profiles: Vietnam, Laos and Cambodia. London: EIU Ltd.

(1995), Country Report: Laos. London: EIU Ltd.

Fforde, Adam (1993), "Vietnamese Commerce: The 'Tiger on a Bicycle' Syndrome," Columbia Journal of World Business, 28 (Winter), 48-55.

Forbes, Dean (1995), "Towards the 'Pacific Century': Integration and Disintegration in the Pacific Basin," in The Far East and Australasia. London: Europa Publications Ltd, 24-38.

Fukushima, Glen S. (1995), "Cold War Contradictions," Tokyo Business Today, 63, 12, 48.

General Statistics Office (1995), unpublished raw data, Hanoi. (1996), Vietnam: The Blazing Flame of Reforms. Hanoi: Statistical Publishing House.

Glassman, R.M. (1991), China in Transition: Communism, Capitalism and Democracy. New York: Praeger.

Goh Keng Swee (1995), Wealth of East Asian Nations. Singapore: Federated Publications.

Gold, Thomas (1986), State and Society in the Taiwan Miracle. New York: M.E. Sharpe.

Goldman, Marshall (1991), What Went Wrong with Perestroika. New York: W.W. Norton.

Goodenough, Ward (1971), Culture, Language and Society. Reading, MA: Addison Wesley.

Goodman, Allan E. (1996), "The Political Consequences of Normalization of U.S.-Vietnam Relations," Contemporary Southeast Asia, 17 (March), 420-29.

Haggard, Stephan and Tun-jen Cheng (1987), "State and Foreign Capital in the East Asian NICs," in The Political Economy of the New Asian Industrialism, Frederic Deyo, ed. Ithaca, NY: Cornell University Press.
Hewison, Kevin, Richard Robison, and Garry Rodan (1993), Southeast Asia in the 1990s: Authoritarianism, Capitalism and Democracy. Sydney: Allen \& Unwin.

Hofstede, Geert (1980), Culture's Consequences: International Differences in Work-Related Values. Beverly Hills, CA: Sage Publications.

International Monetary Fund (1994), Economic Reviews, No. 8: Cambodia. Washington, DC: IMF.

Johnson, Chalmers (1987), "Political Institutions and Economic Performance: The Government-Business Relationship in Japan, South Korea, and Taiwan," in The Political Economy of the New Asian Industrialism, Frederic Deyo, ed. Ithaca, NY: Cornell University Press.

Kamm, Henry (1995), "In Prosperous Singapore, Even the Elite Are Nervous about Speaking Out," The New York Times, (August 13), 1, 6.

Kapstein, Ethan (1996), "Workers and the World Economy," Foreign Affairs, 74 (May/June), 16-37.

Karnow, Stanley (1991), Vietnam: A History. New York: Penguin. (1996), "Vietnam Now," Smithsonian, (January), 32-43.

Keyfitz, Nathan (1982), "Development and the Elimination of Poverty," Economic Development and Cultural Change," 30 (6), 346-55.

Kim, Samuel (1996), "North Korea in 1995," Asian Survey, 36 (January), 61-72.

Kopits, George and Erik Offerdal (1994), "Fiscal Policy in Transition Economies: A Major Challenge," Finance \& Development, 31 (December), 2-24.

Kotler, P. (1994), Marketing Management. Englewood Cliffs, NJ: Prentice Hall.

Kraar, Louis (1993), "Importance of Chinese in Asian Business," Journal of Asian Business, 9 (Winter), 87-94.

Kyi May Kaung (1995), "Theories, Paradigms, or Models in Burma Studies," Asian Survey, 35 (November), 1030-41.

Lao Peoples Democratic Republic (1995), "Basic Data and Economic Indicators," New York, Permanent Mission of LPDR to the United Nations and Vientiane, the Statistical Center of the LPDR.

Lasserre, Philippe and Hellmut Schütte (1995), Strategies for Asia Pacific. London: Macmillan.

Le Ngoc Hung and Dennis Rondinelli (1993), "Small Business Development in Vietnam," Journal of Asian Business, 9 (Fall), $1-23$.

Le Van Bang (1995), [Vietnam's ambassador to the US] speech given at Columbia University, April 29, New York.

Leger, John M. (1995), "Rags to Riches," Far Eastern Economic Review, (October 5), 46-52.

Lizée, Pierre P. (1996), "Cambodia in 1995," Asian Survey, 36 (January), 83-88.

Ljunggren, Börje (1992), Market Economies Under Communist Regimes: Reform in Vietnam, Laos and Cambodia, doctoral dissertation, Southern Illinois University.

(1993), The Challenge of Reform in Indochina. Cambridge, MA: Harvard Institute for International Development.

MacIntyre, Andrew (1994), Business and Government in Industrialising Asia. St. Leonards, Sydney: Allen \& Unwin. 
Marer, Paul and Salvatore Zecchini (1991), The Transition to a Market Economy, 1. Paris: OECD.

McVey, Ruth (1992), "The Materialization of the Southeast Asian Entrepreneur," in Southeast Asian Capitalists, Ruth McVey, ed. Ithaca, NY: Cornell Southeast Asia Program, 7-33.

Meade, William K. and Robert Nason (1991), "Toward a Unified Theory of Macromarketing: A Systems Theoretic Approach," Journal of Macromarketing, 11 (Fall), 72-82.

Mydans, Seth (1996), "Side by Side Now in Cambodia: Skulls, Victims and Victimizers," The New York Times, (May 27), Al.

Naya, Seiji Finch and Joseph L.H. Tan (1995), Asian Transitional Economies. Singapore: Institute of Southeast Asian Studies.

Nguyen Duy Khien (1996), [Deputy General Secretary, VCCI] Panel discussion comments, Markets and Marketing Opportunities in Vietnam Conference, Phoenix, AZ (April 19).

Overholt, William (1993), The Rise of China. New York: W.W. Norton.

Parrinder, Geoffrey (1995), "The Religions of Asia," in The Far East and Australasia. London: Europa Publications Ltd., 15-24.

Pecotich, Anthony and Hock Hwa Chia (1992), "The Role of Multinational Corporation Characteristics and Strategic Actions in the Development of ASEAN Regionalism," Journal of Global Marketing, 5 (3), 63-87.

, Nataša Renko, and Clifford J. Shultz II (1994), "Yugoslav Disintegration, War and Consumption in Croatia," in Research in Consumer Behavior: Consumption in Marketizing Economies, Vol. 7, C. Shultz, R. Belk, and G. Ger, eds. Greenwich, CT: JAI Press, 1-27.

Petri, Peter (1993), The Lessons of East Asia: Common Foundations of East Asian Success. Washington, DC: World Bank.

- (1995), "The Lessons of East Asian Success: A Primer for Transitional Economies," in Asian Transitional Economies, S.F. Naya and J.L.H. Tan, eds. Singapore: Institute of Southeast Asian Studies, 26-55.

Pike, Douglas (1992), "Vietnam in 1991: The Turning Point," Asian Survey, 31 (January), 74-81.

Pollay, Richard, David Tse, and Z. W. Wang (1990), "Advertising, Propaganda and Value Change in Economic Development," Journal of Business Research," 20 (2), 83-95.

Prasso, Sheri (1994), "Cambodia: A Heritage of Violence," World Policy Journal, 11 (Fall), 71-77.

Rigg, Jonathan (1995), "Managing Dependency in a Reforming Economy: The Lao PDR,"Contemporary Southeast Asia, 17 (September), 147-72.

Robison, Richard and David S. G. Goodman (1996), The New Rich in Asia. London: Routledge.

Rondinelli, Dennis, John Nellis, and G. Shabbir Cheema (1983), "Decentralization in Developing Countries: A Review of Recent Experience," World Bank Staff Working Paper No. 581. Washington, DC: World Bank.

Ross, James (1994), [Resident Representative, Cambodia International Human Rights Group], speech at the Columbia University School of International and Public Affairs, September 29, New York.

Ruderman, Peter (1996), "Legal Issues in Vietnam," Markets and Marketing Opportunities in Vietnam Conference, Phoenix, AZ (April 19).
Sakakibara, Eisuke (1995), "The End of Progressivism," Foreign Affairs, 74 (5), 8-14.

Schultz, Theodore (1960), "Capital Formation by Education," Journal of Political Economy, 68 (December), 571-83.

Schwab, Klaus and Claude Smadja (1994), "Power and Policy: The New Economic World Order," Harvard Business Review, 72 (November/December), 40-50.

Schwarz, Adam (1995), "Let That Be a Warning," Far Eastern Economic Review, 158 (47), 23.

Semenik, Richard, N. Zhou, and William Moore (1986), "Chinese Managers' Attitudes Toward Advertising in China," Journal of Advertising, 15 (4), 56-62.

Shenon, Philip (1995), "Cambodia Can't Shake The Legacy of Madness," The New York Times, (March 12), Section 4, 3.

Shultz, Clifford J. II (1994), "Balancing Policy, Consumer Desire and Corporate Interests: Considerations for Market Entry in Vietnam," Columbia Journal of World Business, 29 (Winter), 43-52.

_ and William Ardrey (1997), "Asia's Next Tiger? Vietnam is Fraught With Promise and Peril for Marketers," Marketing Management, 5 (4), 27-37.

, and Anthony Pecotich (1995), "American Involvement in Vietnam, Part II: Prospects for U.S. Business in a New Era," Business Horizons, 38 (March/April), 21-28.

—, Russell W. Belk, and Güliz Ger (1994), Research in Consumer Behavior: Consumption in Marketizing Economies, Vol. 7. Greenwich, CT: JAI Press.

_ and Khai Le (1993), "Vietnam's Inconsistencies Between Political Structure and Socioeconomic Practice: Implications for the Nation's Future," Contemporary Southeast Asia, 15 (September), 179-94.

-, Murray Low, and William Ardrey (in press), Enterprise Management in Transition Economies. New York: United Nations.

- Anthony Pecotich, and Khai Le (1994), "Changes in Marketing Activity and Consumption in the Socialist Republic of Vietnam," in Research in Consumer Behavior: Consumption in Marketizing Economies, Vol. 7, C. Shultz, R. Belk, and G. Ger, eds. Greenwich, CT: JAI Press, 225-57.

Simon, Denis F. (1988), "Technology Transfer and National Autonomy," in Contending Approaches to the Political Economy of Taiwan, Edwin Winkler and Susan Greenlagh, eds. New York: M.E. Sharpe.

Simons, R. (1994), "Striving for Quality Control in China," Asian Advertising and Marketing, (November 4), 10-11.

Solomon, Richard H. (1994), "Asian Architecture-The US in the Asia-Pacific Community," Harvard International Review, 16 (Spring), 26-29.

St. John, Ronald B. (1995), "The Political Economy of the Royal Government of Cambodia," Contemporary Southeast Asia, 17 (December), 265-81.

Steinberg, David I. (1993), "Liberalization in Myanmar: How Real are the Changes?" Contemporary Southeast Asia, 15 (September), 161-78.

Sundhausen, Ulf (1995), "Indonesia's New Order: A Model for Myanmar?” Asian Survey, 35 (August), 769-80.

Swanson, Lauren (1990), "Advertising in China: Viability and Structure," European Journal of Marketing, 14, 277-94. 
(1996), "China: The Changing Consumer," working paper, Chinese University of Hong Kong.

Taft, Sheila (1994), “The Rootless Chinese: Repatriates Transform Economy, Yet Endure Persistent Resentment," Christian Science Monitor, (March 30), 11.

Tan Savuth (1994), [First Secretary of the Permanent Mission to the United Nations of the Kingdom of Cambodia] Interview with author, December 5, New York.

Thein, Myat and Mya Than (1995), "Transitional Economy of Myanmar: Performance, Issues and Problems," in Asian Transitional Economies, S.F. Naya and J.L.H. Tan, eds. Singapore: Institute of Southeast Asian Studies, 210-61.

Tith, Narankhiri and Clifford J. Shultz II (1995), "Cambodia: The Killing Fields, Transition and the Implications for Marketing and Consumer Behavior," working paper, Arizona State University West.

Tran Quang Nghiem (1996), [Chairman of the Vietnamese Government Price Committee] interview with author, January 7, Ho Chi Minh City.

$\rightarrow$ Tse, David, Russell W. Belk, and N. Zhou (1989), "Becoming a Consumer Society: A Longitudinal and Cross-Cultural Content Analysis of Print Ads from Hong Kong, the People's Republic of China and Taiwan," Journal of Consumer Research, 15 (4), 457-72.

United Nations (1992), Conditions for Economic Recovery, 2 (2), doc. GVE92.0.24. New York: United Nations Publications.

(1993a), Development and International Cooperation: Entrepreneurship, doc. A.48.472. New York: United Nations Publications. (1993b), Economic and Social Survey of Asia and the Pacific, Part 2. New York: United Nations Publications.

Vietnam Business Journal (1996), “Axe Falls on Social Evils!” 4 (April ), 18.

Vo Van Kiet (1994), "Keynote Address," Twelfth Williamsburg Conference, New York: The Asia Society.

Wade, Robert (1992), "East Asia's Economic Success," World Politics, 44 (January), 270-320.

The Wall Street Journal (1996), "Economic Freedom Around the World" (May 6), A12.

Wanandi, Jusef (1994), "The Future of ASEAN," Harvard International Review, 16 (Spring), 30-31.

Weidenbaum, Murray (1995), "Isolationism In A Global Economy," Management Review, 84 (12), 43-45.

Williams, Michael (1992), Vietnam at the Crossroads. London: Pinter Publishers.

(1995), "Population in Asia and the Pacific," in The Far East and Australasia. London: Europa Publications Ltd, 3-14.

World Bank (1993), The East Asian Miracle: Economic Growth and Public Policy. Washington, DC: World Bank.

Zakaria, Fareed (1994), "Asia Won't Be a Repeat of Europe's Wartorn Past," Singapore Straits Times, (March 12), 34.

Zhou, Nan and Russell W. Belk (1993), "China's Advertising and the Export Marketing Learning Curve: The First Decade," Journal of Advertising Research, 33 (6), 50-66. 